\title{
Competing Competences in Adjudication: Reviewing the Relationship between the ECOWAS Court and National Courts
}

\author{
Edefe Ojomo \\ Department of Jurisprudence and International Law, University of Lagos, \\ Lagos, Nigeria \\ eojomo@unilag.edu.ng
}

\begin{abstract}
This article argues that regional access to justice in West Africa provides an alternative to national access to justice through the institution of the ECOWAs Community Court of Justice. This gives West Africans the option of pursuing justice in national judicial institutions or in the Ecowas Court. Therefore, it reveals a situation where both systems compete for effectiveness in meeting the justice demands of citizens while also encouraging greater complementarity in their institutional activities.
\end{abstract}

Keywords

ECOWAS - ECOWAS Court of Justice - institutions - jurisdictional hierarchy - regional integration - West Africa

\section{Introduction}

The importance of institution-building in post-independence and post-Cold War Africa, as in most epoch-turning societies, cannot be overemphasized. In the wake of global, regional and national transformations, African countries have striven to develop political - as well as social, cultural, and economic institutions that will stand the test of time. The goal has been to build institutions that will be effective, institutions that will result in the implementation 
of government policy to meet the demands of citizens. ${ }^{1}$ However, effectiveness has not always been the outcome, and the civil and political conflicts that have beset many countries on the continent have been manifestations of this failure of institutions.

Ndulo notes that the post-colonisation environment in Africa was one that came with constraints, such as "underdeveloped human resources, political fragility and insecurity rooted in poorly structured institutions". ${ }^{2}$ These institutional defects lie at the foundation of the continent's socio-economic and political challenges and continue to influence (under)development trends in African countries. ${ }^{3}$ The World Bank noted in 1989 that,

In many African countries the administrations, judiciaries, and educational institutions are now mere shadows of their former selves. This wide-spread institutional decay is symbolized by the poor physical condition of once world-class institutions... by the break-down of judicial systems in a number of countries, by the poor state of once high-quality roads, and by the dilapidation of once well-functioning rail-ways. ${ }^{4}$

'Justice' as a product of functional judicial institutions can be seen as a public good, like roads and railways, which is to be provided for citizens by the

1 This description borrows from Putnam's conception of institutional effectiveness, where he draws a basic chain of events, viz., "societal demands - political interaction - government policy choice - implementation". He notes that "Government institutions receive inputs from their social environment and produce outputs to respond to that environment." In other words, implementation should be about meeting societal demands. See R.D. Putnam, R. Leonardi and R.Y. Nanetti, Making Democracy Work: Civic Traditions in Modern Italy (Princeton University Press, Princeton, NJ, 1993).

2 M. Ndulo, 'The Democratic State in Africa: The Challenges for Institutional Building', 16 National Black Law Journal (1998), 70-101, at p. 72 (emphasis added).

3 See D. Brautigam and S. Knack, 'Foreign Aid, Institutions and Governance in Sub-Saharan Africa', $5^{2}$ Economic Development and Cultural Change (2004), 255-285 (noting at p. 255 that "Poor quality institutions, weak rule of law, an absence of accountability, tight controls over information, and high levels of corruption still characterize many African states today"); See World Bank Public Sector Group, Reforming Public Institutions and Strengthening Governance (World Bank, Washington, DC, 200o), p. 74 (the Bank noted that "In many cases there was little drive for reform of the public sector from the top of governments: the danger of a lowlevel equilibrium exists, in which the incentives to remove poor service are nowhere to be found for any of the actors involved").

4 World Bank, Sub-Saharan Africa:From Crisis to Sustainable Growth (World Bank, Washington, DC, 1989), 22 
government. ${ }^{5}$ However, significant challenges in governance in African countries have meant that the State has been unable to provide justice or to even run functional judicial systems, owing mostly to social and political decay and instability. ${ }^{6}$ In a country like the Gambia, it has been noted that the judicial system "suffers from neglect, under-investment, and a severe lack of resources and infrastructure, resulting from a general deprioritisation of its importance" and that the "actions [of the Gambian government] undermined judicial independence and the rule of law".7 In Nigeria, citizens have sought justice in foreign courts in civil and criminal matters, sometimes after a failed resort to the domestic justice system. ${ }^{8}$ Consequently, judicial reform, which is perhaps one of the most basic means of promoting access to justice, has become a significant part of the discourse on development and governance in Africa as will be shown below.

In theory, "equal justice under law" is difficult to oppose. In practice, however, it begins to unravel at key points, beginning with what we mean by "justice." In most discussions, "equal justice" implies equal access to the justice system. The underlying assumption is that social justice is available through procedural justice. ${ }^{9}$

5 Deborah Rhodes notes that 'law is a public good'. See D. Rhodes, 'Access to Justice', 69 Fordham Law Review (2001), 1785-1821, at p. 1795.

6 Adebajo notes that in some West African countries, the security apparatus, including justice institutions, has been run as the personal preserve of the rulers. See A. Adebajo, Building Peace in West Africa (Lynne Rienner, Boulder, CO, 2002), p. 70, where he states, for instance, that "Liberia's security forces have historically served as an instrument of partisan rule, first defending the interests of Americo-Liberian oligarchy, then keeping the autocratic regime of Doe in power, and ... attempting to ensure the survival of Taylor's regime ... the dispensation of justice is not perceived as neutral".

7 International Bar Association, Under Pressure: A Report on the Rule of Law in the Gambia (International Bar Association, London, 20o6), pp. 5-6, available online at http://www .ibanet.org/Document/Default.aspx?DocumentUid=214e3622-85cf-4219-a151-4194a506a204 (accessed 28 October 2013).

8 See, for instance, Bowoto v. Chevron Texaco Corp., 312 F. Supp. 2d 1229 (N.D. Cal. 2004), concerning a civil action brought by igerians in the us against an American company for acts that occurred in Nigeria; Queen v.James Onanefe Ibori (Case No. T20117192), Southwark Crown Court, 17 April 2012, concerning a criminal action brought against a former Nigerian governor for crimes connected to corruption charges that had been brought against him and dismissed in a Nigerian court; Kiobelv. Royal Dutch Petroleum Co., 133 S.Ct. 1659 (2013), concerning a civil action brought by Nigerians against a Dutch company for acts that occurred in Nigeria.

9 D.L. Rhodes, Access to Justice (Oxford University Press, New York, NY, 2004), p. 5. 
Rhode speaks of access to a 'justice system', implying that this system exists and functions, at whatever level. Access to justice measures are, therefore, those measures that are meant to provide citizens with admission to a 'functioning' justice system and to address specific structural and substantive challenges. Hence, where individuals and groups such as the poor or marginalized have restricted access to the system, this becomes an issue for the State to address. ${ }^{10}$

The institutions that exist to meet citizens' demands may not necessarily always exist at the level of the nation-state. Although international organisations were introduced to regulate international activity on an international plane that consisted mainly of States as the predominant actors, in recent times, these organisations have extended their reach to involve non-State actors and regulate the affairs and activities of such actors. ${ }^{11}$ This has meant that international organisations not only regulate the affairs of States but may also complement the work/activities of States by dealing directly with non-State actors such as individuals. ${ }^{12}$ The past half-century has seen the establishment and evolution of international parliaments, executive institutions, and judiciaries, in the different regions of the world. This phenomenon in Africa is of particular importance because of the rising questionability of State effectiveness and the clamour for intervention in different spheres of State responsibility. ${ }^{13}$ In

10 World Bank, Sub-Saharan Africa: From Crisis to Sustainable Growth (World Bank, Washington, DC, 1989), p. 192, where the Bank noted that rehabilitation of judicial systems was necessary for political renewal, which would restore confidence in government institutions and economic processes; See also V. Maru, 'Access to Justice and Legal Empowerment: A Review of World Bank Practice', World Bank Justice and Development Working Paper Series, volume 9 (World Bank, Washington, DC, 2009).

11 The regulation of state activity is based on the idea that states are the predominant subjects of international law. Therefore, as subjects of international law, these organisations, formed by states, have a prima facie state-centric focus. However, this is not the full story, as discussions about the growing scope of subjects of international law grow. See, for instance, G. Acquaviva, 'Subjects of International Law: A Power-Based Analysis', 38 Vanderbilt Journal of Transnational Law (2005), 315-376, at p. 315; B. Verbeek, 'International Organisations: The Ugly Duckling of International Relations Theory?' in B. Renalda and B. Verbeek (Eds.), Autonomous Policy Making by International Organisations (Taylor \& Francis e-library, London, 2005), p. 11.

12 For instance, Schreuer notes that "The traditional exclusion of non-State actors from the international arena has been subjected to a number of important exceptions and limitations in the course of this century." See C.H. Schreuer, 'Concurrent Jurisdiction of National and International Tribunals', 13 Houston Law Review (1975-1976), 508-526, at pp. 508, 510.

13 In his discussion of state failure, Kreijen notes that the phenomenon is common throughout the African sub-continent. He goes on to describe it as "the absence of meaningful governmental structures within the state." See G. Kreijen, State Failure, Sovereignty, and: 
response to global, regional and national vicissitudes, African governments have become members of and established global, regional and national institutions. The interactions between and among such institutions are important, not only for resolving disputes and ensuring synergies but, more importantly, for ensuring that the demands of citizens (be they national, regional or global) are met; ${ }^{14}$ in other words, institution-building is on-going at different levels of political organization.

This article will assess one of the institutions of the Economic Community of West African States (ECOWAS), the ECOWAS Court of Justice, and see how it has evolved and been shaped to meet citizens' demands at the regional level. It will also seek to address the question whether regional integration - and in essence, supra-national institutions - can be used to address national challenges in a way that meets the demands of citizens. The paper will argue that the ECowas Court was established to address national challenges in justice sector performance and, in a sense, act as an alternative to failing institutions in Member States. The article will argue that regional integration in the African context can - and should - be used to address national institutional deficits, while also contributing to the development of stronger national institutions. The focus of this work is the interpretation of relevant EcowAs instruments in determining how the EcowAS Court relates with Member State judicial systems, and not vice versa. In other words, this paper does not look at the ways in which national courts relate with the EcowAs Court.

The first part of the article will discuss the experience of regional integration in West Africa, with an aim to addressing concerns about the performance of institutions in West African States and the introduction of a regional response. The second part of the paper will provide a detailed explanation of the establishment, functions, and competence of the Ecowas Community Court of Justice. The third part will examine the relationship between national and international tribunals, and it will argue that, unlike most other international tribunals, the ECOWAs Court operates on the same plane as national courts in Member States and provides an alternative for citizens in search of greater effectiveness in justice delivery. In other words, there is a system of competing competences, allowing citizens to choose where to make their demands.

Legal Lessons from the Decolonisation of Sub-Saharan Africa (Martinus Nijhoff, Leiden, 2004), p. 101.

14 Theoretically, the concept of citizenship in Africa has moved beyond the nation-state to include regional conceptions of citizenship. Regional institutions, such as the Economic Community of West African States, have introduced citizenship status and ensuing rights at the regional level. 
All West African States, ${ }^{15}$ except Liberia, experienced colonization, which saw the introduction of present-day political institutions. While it is true that before the advent of colonialism, these 'new' States and their sub-state components possessed socio-political and cultural structures that provided the relevant governance mechanisms, the contemporary institutions in these States are based on structures and institutions introduced by colonial powers.

West African States have worked to address their institutional deficits and promote economic growth and development. One of the ways they have done this is through regional integration. Although concrete discussions about regional integration in Africa began at the start of the 2oth century, the real returns were not realized until about half a century later. ${ }^{16}$ The next halfcentury saw a proliferation of regional and sub-regional institutions on the continent, and today, there are more regional institutions in Africa than any other region in the world. The continent is a 'spaghetti bowl' of regional organisations, many of which have overlapping membership and obligations. ${ }^{17}$ In this regard, West Africa is a microcosm of the African condition, with several intergovernmental organizations in a region with fewer than twenty countries. ${ }^{18}$

The foremost intergovernmental organization in West Africa is the Economic Community of West African States (ECOWAS), which was established in 1975 with the adoption of the Lagos Treaty by the leaders of fifteen West African

15 Since this paper focuses on West African integration in the light of the Ecowas experience, references to West Africa will necessarily mean Ecowas Member States, viz: the Republic of Benin, Burkina Faso, Cape Verde, Cote d'Ivoire, the Gambia, Ghana, Guinea, Guinea-Bissau, Liberia, Mali, Niger, Nigeria, Senegal, Sierra Leone and Togo.

16 See A. Ajala, 'Background to the Establishment, Nature and Structure of the Organisation of African Unity', 14 Nigerian Journal of International Affairs (1988), 35-63; J.C. Senghor et al., Going Public: How Africa's Integration can work for the Poor (African Research Institute, London, 2009), p. 22.

17 Senghor et al, supra note 16, p. 18.

18 There are three main regional organisations in West Africa, viz, EcowAs, Mano River Union (MRU) - Guinea, Liberia, Sierra Leone and Ivory Coast; Union Economique et Monetaire Ouest Africaine (UEmoA) - Burkina Faso, Cote d'Ivoire, Guinea Bissau, Mali, Niger, Republic of Benin, Senegal, Togo. The Community of Sahel-Saharan States (CENSAD) also has a membership that spans West Africa, Central Africa, East Africa and North Africa. ECOWAS as a purely West African 15 -State strong membership constitutes the exclusively West African institution with the widest coverage. 
countries. ${ }^{19}$ Under the 1975 Treaty, integration was expected "to promote cooperation in all fields of economic activity ... for the purpose of raising the standard of living of... people, of increasing and maintaining economic stability, of fostering closer relations among... members and of contributing to the progress and development of the African continent." ${ }^{20}$ In furtherance of this broad development objective, Article 2(2) of the 1975 Treaty set out [mainly economic] principles geared towards achieving the goals of integration. ${ }^{21}$ Interestingly, some of the Community's objectives and functions were targeted at 'citizens' of the Community, revealing a focus on peoples or individuals. For instance, the Lagos Treaty makes reference to the Community Citizen, ${ }^{22}$ as does the 1979 Protocol Relating to Free Movement of Persons, Residence and Establishment. ${ }^{23}$ In 1982, a Protocol was adopted, which defined the term "Community Citizen". That Protocol provides a detailed overview of who constitutes a Community Citizen, and how citizenship is acquired and lost. Despite these provisions, however, the position of the individual in the integration process has remained weak, ${ }^{24}$ but as will be shown below, there have been efforts to ensure that the benefits of integration accrue to Community citizens.

By the 1990s, the face of integration in West Africa had changed considerably, as socio-political and economic challenges led to instability in Member States. ${ }^{25}$ In 1993, the Lagos Treaty was revised and the scope of the objectives,

19 The original members of the Community were the Republic of Benin, Burkina Faso, Cote d'Ivoire, the Gambia, Ghana, Guinea, Guinea-Bissau, Liberia, Mali, Mauritania, Niger, Nigeria, Senegal, Sierra Leone and Togo. Cape Verde was admitted in 1978, bringing the membership to 16, but Mauritania withdrew its membership in 2000, bringing the membership back to 15 .

$20 \quad$ Article 2(1), EcowAs Treaty, 1975

21 There were 10 paragraphs in this subsection, nine of which covered specific economic and trade goals and policies necessary for economic advancement, and the tenth was an omnibus clause that empowered the Community to undertake "such other activities calculated to further the aims of the Community as the Member States may from time to time undertake."

22 Article 27 provides that "Citizens of Member States shall be regarded as Community Citizens..."

23 Protocol A/P 1/5/79

24 See Senghor et al., supra note 16.

25 Civil wars broke out in Liberia and Sierra Leone and there were successful military coups in almost every other country in the sub-region. For details of the region's security challenges and their historical origins and implications, see generally S. Ellis, The Mask of Anarchy: The Destruction of Liberia and the Religious Dimension of an African Civil War, 2nd edn (Hurst \& Co, London, 2007); A. Bryden, B. N'Diaye and F. Olonisakin (Eds), Challenges of Security Sector Governance in West Africa (Lit, Berlin, 2008); Adebajo, supra 
principles and institutions of the Community was expanded to address social and political concerns, in addition to the economic concerns of the 1970s. Since then, regional integration in West Africa has progressively addressed broad development and institution-building goals, particularly through the establishment of institutions for the regulation of integration and promotion of development in the Community.

Furthermore, in 2006, the administration of the Community was transformed to "endow the Community with greater supranational powers". ${ }^{26}$ The idea was to facilitate a transition from 'an ECOWAs of states to an ECOWAS of people', in an effort to achieve real institutional effectiveness and achieve the goals of integration. ${ }^{27}$

These changes in the regional integration goals and practices of EcowAS also touched on the 'judicial system' of the Community, as a Community Court was established, which came into operation in 2002. Its role was amended in 2005 to, inter alia, directly address the needs of Community citizens as will be further shown below.

Judicial institutions as a core component of the political system cannot be overemphasized, and their proper functioning contributes significantly to state effectiveness. Article 1(c) of the 2001 Ecowas Protocol on Democracy and Good Governance Supplementary to the Protocol relating to the Mechanism for Conflict Prevention, Management, Resolution, Peacekeeping and Security lists independence of the judiciary as one of the constitutional principles shared by Ecowas Member States, noting that judges shall be independent in the discharge of their duties. ${ }^{28}$ This link between the independence of the judiciary and good governance has become a recurring theme in development discourse. Posner and Yoo note, for instance, that

Domestic courts are, in a word, independent, and that independence helps distinguish successful market-based liberal democracies from authoritarian regimes and failed democracies in which corruption is the norm and markets are weak. ${ }^{29}$

note 5; A. Adebajo and I. Rashid (Eds), West Africa's Security Challenges: Building Peace in a Troubled Region (Lynne Rienner, Boulder, CO, 2004).

26 Ecowas Annual Report, 2006, 11. One significant change was that the Executive Secretariat became a Commission with a President and several Commissioners, signifying supra-national governance institution, similar to the European Union.

27 Ibid.

28 Protocol A/SP1/12/01

29 E.A. Posner and J.C. Yoo, 'Judicial Independence in International Tribunals', 93 California Law Review (2005), 1-75, at p. 12. 
Therefore, democracy and good governance demand a properly functioning judicial system that meets the demands of citizens. In West Africa, one of the ways in which the challenges of access to justice and judicial institutions were addressed was through regional integration and the introduction of regional judicial institutions. As Nwauche notes,

Regional human rights protection is often a reaction against the failings of nation states operating on the assumption that the pooled resources of a regional understanding will overcome the weakness of national human rights systems. It is often thought that states with a weak human rights system will change their systems to accord with higher regional normative standards. ${ }^{30}$

This logic is analogical to the establishment of regional institutions in Africa. We will now discuss the experience of the Ecowas Community Court of Justice as a regional judicial system that promotes institutional effectiveness at the state and supra-state levels.

\section{The ECOWAS Community Court of Justice}

One of the institutions established under the 1975 Ecowas Treaty was the Tribunal of the Community. The Tribunal was charged with the responsibility of ensuring the 'observance of law and justice in the interpretation of ... [the] Treaty' and settling disputes amongst Member States of the Community. ${ }^{31}$ While the Treaty in Article 11(1) provided for the establishment of the Tribunal, Article 11(2) empowered the Authority of Heads of State and Government to determine the operational elements of the Tribunal. ${ }^{32}$ This meant that the Tribunal would only become operational upon the exercise by the Authority of

30 E. Nwauche, 'Regional Economic Communities and Human Rights in West Africa and the African Arabic Communities' in A. Bosl and J. Diescho (Eds), Human Rights in Africa: Legal Perspectives on their Promotion and Protection (Macmillan Education Namibia, Windhoek, 2009), p. 318.

31 Article 11(1), 1975 Ecowas Treaty, states the function of the Tribunal, and refers to Article 56 for the jurisdiction of the Tribunal with regard to the settlement of disputes. Article ${ }^{6}$ provides that ' $[\mathrm{a}]$ ny dispute that may arise among the Member States regarding the interpretation or application of this Treaty shall be amicably settled by direct agreement. In the event of failure to settle such disputes, the matter may be referred to the Tribunal of the Community by a party to such disputes and the decision of the Tribunal shall be final.' Article 11(2), 1975 ECOWAS Treaty provides that 'The composition, competence, statutes and other matters relating to the Tribunal shall be prescribed by the Authority'. 
its power under Article 11(2). The Authority never exercised this power in relation to the operation of a 'Tribunal of the Community', but in 1991, it adopted Protocol A/P.1/A1/1991 on the 'Community Court of Justice'. ${ }^{33}$ In Article 1 of the Protocol, 'Court' is defined as 'the Community Court of Justice established by Article 11 of the Treaty', even if Article 11 makes reference to a 'Tribunal of the Community'. Although it would be nice to think that the change in nomenclature from a 'Tribunal', as contained in the 1975 Treaty, to a 'Court of Justice', could be attributed to an attempt to implement a substantive modification of the relevant provisions of the 1975 Treaty, particularly those relating to the functions of the Tribunal, the language of the Protocol seems to ignore the modification and treat it as though there had been no change whatsoever. ${ }^{34}$

The functions of the Court under the 1991 Protocol are similar to the functions of the Tribunal under the 1975 Treaty, referring to Article 56 of the Treaty, restricting the competence of the Court to cases involving the interpretation of the Treaty and the resolution of disputes between Member States inter se and between Member States and institutions of the Community. ${ }^{35}$ The Court was therefore established as an international tribunal for the settlement of disputes between States and intergovernmental organisations.

The Preamble of the Protocol makes reference to Article 5 of the 1975 Treaty (on the establishment, composition and functions of the Authority), Article 4(e) of the 1975 Treaty (the accurate Article listing the Tribunal as one of the institutions of the Community was Article 4(d), so this was an error) and Article 11 of the 1975 Treaty (on the establishment of the Tribunal) as the basis for the establishment of the Community Court of Justice, evincing an intention of the Authority to establish a Court rather than a Tribunal.

34 Article 11 of the Protocol refers to 'Applications to the Tribunal. This is the only place in the Protocol where the institution is referred to as a tribunal.

35 Although Article 56 only refers to disputes between Member States, the Protocol includes institutions of the Community as competent parties before the Court. The Preamble of the Protocol states that

"the essential role of the Community Court of Justice is to ensure the observance of law and justice in the interpretation and application of the Treaty and the Protocols and Conventions annexed thereto, and to be seized with responsibility for settling such disputes as may be referred to it in accordance with the provisions of Article 56 of the Treaty and disputes between States and the Institutions of the Community" (emphasis added),

while Article 9(2) provides that

"The Court shall also be competent to deal with disputes referred to it, in accordance with the provisions of Article 56 of the Treaty, by Member States or the Authority, when such disputes arise between the Member States or between one or more Member States and the Institutions of the Community on the. interpretation or application of the provisions of the Treaty" (emphasis added) 
The 1993 Revised Treaty was adopted shortly after the 1991 Protocol on the Court came into force. This Treaty provides for the establishment of a Community Court of Justice in Articles 6 and 15. The functions and competence of the Court remained the same during the first decade of the Protocol coming into force. However, in the 2001 Supplementary Protocol on Democracy and Good Governance, ${ }^{36}$ a provision reviewing the 1991 Protocol extended the competence of the Court to cover actions involving the violation of human rights and the exhaustion of local remedies rule was introduced for such actions brought before the Court. The relevant provision states that

Protocol A/P.1/7/91 adopted in Abuja on 6 July 1991 relating to the Community Court of Justice, shall be reviewed so as to give the Court the power to hear, inter-alia, cases relating to violations of human rights, after all attempts to resolve the matter at the national level have failed.

This provision was relative to the 1991 Protocol, under which, as noted above, individuals were not competent to bring actions before the Court. Therefore, the 2001 Protocol modified the functions and competence of the Court to include the power to determine cases involving the violation of human rights. When read in line with the provisions of Article 9 on the competence of the Court, this additional power of the Court can be interpreted to cover only those human rights actions brought by member States on behalf of their citizens. The introduction of this modification could be attributed to the inclusion of Article 4(g) in the 1993 Revised Treaty, which provides that Member States affirm and declare their adherence to the principle of "recognition promotion and protection of human and peoples' rights in accordance with the provisions of the African Charter on Human and Peoples' Rights", a provision that was not present in the 1975 Treaty. This provision, as will be shown below, is a significant part of the jurisprudence of the Court in determining its human rights jurisdiction.

Again, in 2005, a Supplementary Protocol to the 1991 Protocol $^{37}$ was adopted, and it contained provisions that extended the competence of the Court as well as the rules relating to access to the Court. Article 3 substituted the old Article 9 with a new one that deals with the 'Jurisdiction of the Court', which,

36 Note that not all Member States have ratified this Protocol. For instance, the Nigerian government has not ratified the Protocol.

$37 \quad(\mathrm{~A} / \mathrm{SP} .1 / 01 / 05)$ 
inter alia, extends the jurisdiction of the Court to "determine cases of violation of human rights that occur in any Member State". 38

Article 4 inserts a new Article 10 on Access to the Court, which extends access beyond member states and the Authority, to include individuals and corporate bodies. The new Article 10(d) provides that,

Access to the Court is open to...

Individuals on application for relief for violation of their human rights; the submission of application for which shall:

i. Not be anonymous; nor

ii. Be made whilst the same matter has been instituted before another International Court for adjudication

The 2005 Supplementary Protocol thus creates a new kind of Court that provides access to different subjects of international law, including corporate bodies and individuals. The Protocol introduced a Court that would become the regional institution through which the rights of Community citizens could be protected. By expanding the scope of the Court's jurisdiction, however, questions relating to the relationship between the Court and national courts

38 Article 3 provides for the expansion of the jurisdiction of the Court to include: "[ $t]$ he interpretation and application of the Treaty, Convention and Protocols of the Community; the interpretation and application of the regulations, directives, decisions, and other subsidiary legal instruments adopted by EcowAs; the legality of regulations, directives, decisions and legal instruments adopted by EcowAs; the failure by Member States to honor their obligations under the Treaty, Convention and Protocols, regulations, directives, or decisions of ECOWAs; the provisions of the Treaty, Convention and Protocols, regulations, directives, or decisions of Ecowas Member States; the Community and its officials; the action for damages against a Community institution or an official of the Community for any action or omission in the exercise of official functions; ... the power to determine any contractual liability of the Community and... order the Community to pay damages or make reparation for any acts or omissions of any Community institution or Community officials in the performance of official duties or functions; ... the jurisdiction to determine cases of violations of human rights that occur in any Member State; ... the power to act as arbitrator for the purpose of Article 16 of the Treaty; jurisdiction over any matter provided for in an agreement where the parties provide that the Court shall settle disputes arising from the agreement;... the powers conferred upon it by the provisions of this Protocol as well as any other powers that may be conferred by subsequent Protocols and Decisions of the Community"

The new Article 9(8) grants the Authority of Heads of State and Government "the power to grant the Court the power to adjudicate on any specific dispute that it may refer to the Court other than those specified in this Article". 
and institutions become pertinent, especially as the Protocol does not make expansive reference to such a relationship, not even with regard to the exhaustion of local remedies. ${ }^{39}$

Although the Protocol and the Supplementary Protocol are almost silent with regard to the relationship between the Court and national institutions, ${ }^{40}$ the Court has developed an impressive jurisprudence with regard to the issue. The following section will provide a brief analysis of the relationship between international tribunals and domestic courts, then it will look at the developing body of case law on the relationship between the EcowAs Court and the courts of Member states; then, it will attempt to situate the EcowAS experience within the general discourse.

\section{4} Competing Competences in Adjudication?

\subsection{Some General Rules on Jurisdictional Relations between National and International Courts}

Domestic tribunals should be the first port of call for private individuals and juristic persons seeking justice in the form of rights protection, dispute resolution, or other kinds of legal matters. However, with the rise in the number of international tribunals, it has become possible, and in many cases desirable, ${ }^{41}$ for natural and juristic persons to settle their disputes or seek the protection

39 As will be seen below, the Court is silent on the question of exhaustion of local remedies, which is recognized in most international human rights instruments that grant individuals access to international courts and tribunals.

The new Article 9(f) introduced in the 2005 Supplementary Protocol contains a provision on preliminary ruling.

41 See, for instance, L.R. Helfer and A.-M. Slaughter, 'Toward a Theory of Effective Supranational Adjudication', 107 Yale Law Journal (1997), 273-391, at pp. 273, 274, where the authors note that "... the European Court of Justice (ECJ) and the European Court of Human Rights (ECHR) have convinced national governments, individual litigants, and the European public to endorse and participate in frequent and often high-stakes adjudication at a level above the nation-state... [and that] both tribunals developed successful strategies to make their judgments as effective, for the most part, as national court rulings." This indicates a 'happy' acceptance by individuals of this 'other' source of justice delivery. In additions to individuals, even governments have promoted the establishment of these supra-national justice systems with individual access. See A. Moravcsik, 'The Origins of Human Rights Regimes: Democratic Delegation in Postwar Europe', 54 International Organisation (2000), 217-252, at pp. 243-244, where the author claimed that the establishment of the human rights regime of the European Community lay “... in self-interested efforts by newly established (or reestablished) democracies to employ international 
of their rights in such tribunals. This has meant that international law and international institutions have had to intervene in the determination of rights and duties that were previously within the exclusive domain of national law and institutions. ${ }^{42}$ This may raise questions about when or whether the sovereignty of a State has been violated or whether an international institution has interfered in the domestic affairs of a State, in violation of Article 2(7) of the United Nations Charter. ${ }^{43}$ Therefore, it is important to examine the relevance, or otherwise, of the shift from national to international adjudication and the relationship between international tribunals and their domestic counterparts.

The proliferation of international tribunals has become an important topic amongst international lawyers and jurists. ${ }^{44}$ These tribunals have jurisdiction

commitments to consolidate democracy - "locking in" the domestic political status quo against their nondemocratic opponents."

This is particularly true with regard to the protection of human rights, an area of legal protection that has taken an international dimension since the end of the Second World War. See L.B. Sohn, 'The New International Law: Protection of the Rights of Individuals rather than States', 32 American University Law Review (1982), 1-64. Shany also notes that 'the rate of usage of international courts has risen markedly, as has the role of individuals and international organisations in international court proceedings'. See Y. Shany, 'No Longer a Weak Department of Power? Reflections on the Emergence of a New International Judiciary', 20 European Journal of International Law (2009), 73-91, at p. 75.

43 See K.J. Alter, 'Delegating to International Courts: Self-Binding vs. Other-Binding Delegation', 71 Journal of Law and Contemporary Problems (2008), 37-76; S. Beeson, 'The Authority of International Law - Lifting the State Veil', 31 Sydney Law Review (2009), 343380. Article 2(7) provides that "Nothing contained in the present Charter shall authorize the United Nations to intervene in matters which are essentially within the domestic jurisdiction of any state or shall require the Members to submit such matters to settlement under the present Charter; but this principle shall not prejudice the application of enforcement measures under Chapter VII"; cf., Helfer and Slaughter, supra note 41, p. 273, 288 (speaking of the interlinkages between sovereignty and accountability in the provision of supranational justice systems, which makes such an effort a step in the direction of enhancing performance of government institutions).

44 See Y. Shany, 'Assessing the Effectiveness of International Law: Can the Unquantifiable be Quantified?', International Law Forum, Hebrew University of Jerusalem, Research Paper No. 03-10 (2010); Shany, supra note 42, p. 73; Y. Shany, The Competing Jurisdiction of International Courts and Tribunals (Oxford University Press, Oxford, 2003); C. Brown, 'The Proliferation of International Courts and Tribunals: Finding your Way through the Maze', 3 Melbourne Journal of International Law (2002), 453-475; S. Spelliscy 'The Proliferation of International Tribunals: A Chink in the Armor', 40 Columbia Journal of Transnational Law (2001-2002), 143-175; N. Lavranos 'Regulating Competing Jurisdictions Among International Courts and Tribunals', 68 Zeitschrift für ausländisches öffentliches Recht und Völkerrecht (2008), 575-621. 
over and usually hear cases between States inter se, States and non-State actors, and States or certain non-State actors on the one hand and private actors on the other; many of these cases involve border disputes, trade disputes and human rights issues, amongst others. ${ }^{45}$ International tribunals operate on a horizontal plane in which there is no hierarchy to determine their relationship with one another; therefore, the proliferation of such institutions raises questions about the resolution of contradictions between judgments and awards, as the case may be, as well as the need to institutionalize the relations between these tribunals. ${ }^{46}$ This is a very interesting phenomenon that continues to receive widespread attention, as it provides an interesting dimension to the quest for mandatory or vertical enforcement mechanisms under international law.

Somewhat related to this phenomenon is the similarly - perhaps even more - troublesome question of the relationship between international tribunals and domestic tribunals. Although there is no universally accepted position on the nature of the relationship between international law and municipal law, it is suggested that both operate on different spheres. ${ }^{47}$ This makes it easier to regulate the relationship between international and domestic tribunals, as many treaties establishing international tribunals or governing international jurisdiction will usually contain some reference to the position of domestic courts, as will be shown below.

There are several rules that determine the relationship between tribunals, and, in its discussion of the relationship between national and international institutions, this article will focus on some jurisdiction-regulating rules that

45 See Alter, supra note 43, p. 61. International litigation here deals with cases involving States inter se and against other international legal persons, and is distinct from transnational litigation, which 'encompasses domestic and international tribunals... [and] includes cases between states (with individuals typically in the wings), between individuals and states, and between individuals across borders', see A.-M. Slaughter, 'The Global Community of Courts', 44 Harvard International Law Journal (2003), 191-219, at p. 192.

46 On the issue of the institutionalization of an international justice system, see Shany, supra note 41; Shany, The Competing Jurisdiction of International Courts and Tribunals, supra note 43; M. Pinto, 'National and International Courts - Deference or Disdain?', 30 Loyola of Los Angeles International and Comparative Law Review (2008), 247-275; Spelliscy, supra note 44; Posner and Yoo, supra note 29; See also Shany, supra note 41, p. 907, arguing that there should be a general recognition and application of the doctrine of margin of appreciation by international tribunals, particularly the ICJ.

47 See Pinto, supra note 46; Y. Shany, Regulating Jurisdictional Relations between National and International Courts (Oxford University Press, Oxford, 2007). 
determine access to such institutions by disputing parties. ${ }^{48}$ The main focus of this paper will be the exhaustion of local remedies rule, which is a rule of admissibility and a principle of customary international law that has been employed significantly by international human rights tribunals and provides a prima facie interpretation of the relationship between domestic and international tribunals. Where there is an application of the local remedies rule, other jurisdiction-regulating rules may not apply, because of the automatic presumption of a hierarchical relationship between the courts or institutions in question. This will be discussed further below.

With regard to the spheres of jurisdiction of national courts and international courts, there is a much less acknowledged confirmation of distinction, as both spheres overlap in different areas of jurisdiction. ${ }^{49}$ However, such overlap may be regulated by the existence of a jurisdictional hierarchy in the relations between those courts (something that does not necessarily exist in say the relations between international tribunals inter se). ${ }^{50}$ Where such a hierarchy does not exist, we can assume that there will be a horizontal relationship between the different systems, national and international (somewhat similar to what exists between international tribunals inter se). The hierarchical vertical relationship may promote the supremacy of the international tribunal or the national tribunal, while a non-hierarchical horizontal relationship would usually promote a system of alternatives in which parties can choose between competing systems. The recognition of hierarchy itself presents a "jurisdictionregulating regime", according to Shany, and "the establishment of hierarchical relations negates the possibility of viewing parallel proceedings as judicial alternatives to one another". ${ }^{51}$ Therefore, where there is a hierarchical relationship between such institutions, they cannot compete with each other as

48 In his study of the relations between national and international relations, Shany looks at treaty-based jurisdiction regulating rules such as the exhaustion of local remedies, the preliminary ruling rule, the doctrine of complimentarity, electa una via, and the recognition of international arbitral awards. He notes that while the first two indicate a vertical hierarchical relationship between national and international institutions, the last three represent horizontal non-hierarchical relations between the parties. See Shany, supra note 47 .

49 See Shany, supra note 47; Shany, supra note 44, p. 10.

5o See Shany, supra note 47, p. 6.

$5^{1} \quad$ Ibid., p. 88. However, this rule is not in itself exhaustive as it can lead to challenges of coordination such as the parallel litigation of identical courses and consequent logistical, financial and resource-based complications. Therefore, other jurisdiction-regulating rules (for example, the exhaustion of local remedies rule or preliminary ruling) would usually be employed in a hierarchical situation to deal with such issues. Ibid. 
the relationship would usually involve power relations requiring the review of one system by another. ${ }^{52} \mathrm{~A}$ non-hierarchical relationship reveals competition, alternatives and dialogue..$^{53}$

As noted earlier, relevant constitutive treaties usually define the relationship between national and international tribunals, and here, rules such as the exhaustion of local remedies, ${ }^{54}$ preliminary ruling, the doctrine of complimentarity, electa una via, and the recognition of international arbitral awards may come into play. Where the treaty does not provide for an express jurisdictionregulating rule, the court may determine how to handle the complexities of jurisdictional overlaps. ${ }^{55}$

The legal instrument conferring jurisdiction is usually the first place to look in determining the existence of a jurisdiction-regulating rule, which might reveal a hierarchical or non-hierarchical relationship between the different courts capable of exercising jurisdiction. In Electricity Company of Sofia, ${ }^{56}$ the PCIJ had to decide whether an action brought before it by Belgium, on behalf of a Belgian company, against Bulgaria, during the pendency of a suit in the Bulgarian Court of Cassation, was 'premature and irregular'. The Court took into consideration the content of the relevant treaty between the parties granting it jurisdiction, noting that

The local remedies rule contemplated by the Treaty of 1931 implies the exhaustion of all appeals, including appeals to the Court of Cassation, a decision by which alone renders the judgment final either by annulling the judgment of the Court of Appeal and sending the case back for a retrial, or by rejecting the appeal..$^{57}$

Therefore, where the appeal was pending at the time of institution of the international case, but was determined shortly thereafter, the Courts decided, based on the special circumstances of that case, that the application was irregular. It held that

52 See R. Ahdieh, 'Between Dialogue and Decree: International Review of National Courts', 79 New York Univeristy Law Review (2004), 2029-2163.

53 Ibid.; Shany, supra note 47.

54 Shany recognizes the exhaustion of local remedies rule as a 'clear hierarchy signifier'. Shany, supra note 44. See also Shany, supra note 47, p. 28.

55 See Shany, supra note 47, p. 39.

561939 P.C.I.J. (ser. A/B) No. 77 (4 April), available online at www.worldcourts.com/pcij/ eng/decisions/1939.04.04_electricityı.htm (accessed 28 October 2013).

57 Ibid., para. 76 . 
...the irregularity of the Belgian Application was not removed by the judgment rendered on March 16th, 1938, by the Bulgarian Court of Cassation, for in the meantime, i.e. on February 4th, 1938, the Treaty of 1931 had expired, having been denounced by the Bulgarian Government.

Accordingly, since the Belgian Application has not been submitted in accordance with the conditions laid down by the Treaty of 1931, the Belgian Government cannot found the jurisdiction of the Court on that Treaty. ${ }^{58}$

As indicated in the Sofia judgment, the Court will always look at the treaty(ies) and instrument(s) governing jurisdiction in any matter, affirming the "treatybased, category-specific nature of the jurisdiction of most international tribunals".59 In some situations, as will be shown below, these treaty provisions may require the exhaustion of local remedies. Therefore, rules relating to the exhaustion of local or other legal remedies are usually based on treaty provisions that ensure that the parties exhaust other (national) avenues for the resolution of their dispute before approaching the international tribunals.

The agreement between the parties granting jurisdiction to the Court is an important determinant of the effect of pending or parallel litigation, as it is a signifier of the relationships between different tribunals seized with jurisdiction over similar matters, in other words, overlapping or competing jurisdiction. We will now look briefly at some jurisdiction-regulating rules.

\subsection{Exhaustion of Local Remedies}

The rule relating to the exhaustion of local remedies, referred to above, has been recognized as a rule of customary international law, which requires parties to exhaust local remedies in actions against other state parties before exercising the diplomatic protection of their nationals in international tribunals. As opposed to being a rule of jurisdiction, this is a rule of admissibility that determines whether or not the Court will entertain a particular suit, based on the procedural validity of the application. The application of the rule has been extended to cases involving individuals and states in international tribunals. ${ }^{60}$

With regard to litigation concerning human rights violations brought by individuals against state governments, the relationship between the relevant

$5^{8} \quad$ Ibid., paras $79-80$.

59 J. Pauwelyn and L.E. Salles, 'Forum Shopping Before International Tribunals: (Real) Concerns (Im)Possible Solutions'. 42 Cornell International Law Journal (2009), 77-118.

6o See generally C.F. Amerasinghe, Local Remedies in International Law, 2nd edn (Cambridge University Press, Cambridge, 2004). 
international tribunals and municipal courts is usually determined by the treaties that constitute such tribunals, and will usually contain a provision on the necessity of the exhaustion of local remedies. Although these international tribunals are concerned with the international obligation of states to protect human rights (which is governed by international law under the relevant treaties), many of the rights contained in the international human rights instruments also cover domestic obligations of state parties. Therefore, there are important linkages between both court systems, which would usually require domestic tribunals to handle cases of human rights violations similar to the actions that may be brought before international tribunals. Domestic courts, under this rule, are expected to handle such cases before they are brought before international tribunals by dissatisfied parties, thus ensuring that state parties have the opportunity to govern their domestic affairs before such matters are brought before an international tribunal. In SERAC V. Nigeria, ${ }^{61}$ the African Commission on Human and Peoples' Rights noted that

One purpose of the exhaustion of local remedies requirement is to give the domestic courts an opportunity to decide upon cases before they are brought to the international forum, thus avoiding contradictory judgments of law at the national and international levels.

Again, in Zimbabwe Lawyers for Human Rights \& Associated Newspapers of Zimbabwe v. Zimbabwe, ${ }^{62}$ the African Commission stated that

International mechanisms are not substitutes for domestic implementation of human rights, but should be seen as tools to assist the domestic authorities to develop a sufficient protection of human rights in their territories. If a victim of a human rights violation wants to bring an individual case before an international body, he or she must first have tried to obtain a remedy from the national authorities. It must be shown that the state was given an opportunity to remedy the case itself before resorting to an international body. This reflects the fact that states are not considered to have violated their human rights obligations if they provide genuine and effective remedies for the victims of human rights violations.

The application of this rule can be interpreted as recognition of the sovereign power of states to handle their domestic affairs, espoused in Article 2(7) of the

\footnotetext{
61 (2001) AHRLR 60 (ACHPR 2001) p. 65, para. 34 .

62 (2009) AHRLR 235 (ACHPR 2009) p. 251, para. 100.
} 
UN Charter, and an expression of the doctrine of comity. ${ }^{63}$ It also has the operational function of controlling the multiplicity of same or similar proceedings in national and international tribunals, which could lead to 'divergent conclusions'.64 In addition to these functions, the exhaustion of local remedies rule, as noted in the Zimbabwe case, gives States the opportunity to comply with their international obligation before subsequent review of (non)compliance is brought before an international tribunal or institution.

Many of the instruments governing international human rights tribunals contain a provision requiring the prior exhaustion of local remedies before cases are brought before such tribunals. ${ }^{65}$ It is these instruments that define the jurisdiction of the relevant tribunals, amongst other things; therefore, where such explicitly stated requirements are not met, the tribunal will refuse to exercise jurisdiction over the matter. This rule creates a hierarchical relationship between international tribunals and domestic tribunals so that the international tribunal, which hears a case after it must have gone through a domestic process, usually has a power of review over the domestic process. ${ }^{66}$

From the above, it is clear that international and domestic tribunals operate on different spheres, but there may be linkages in their jurisdiction based on the parties or the cause of action. While rules such as res judicata and lis alibi pendens may not necessarily apply in the regulation of jurisdiction in vertical hierarchical relations, the treaties or other legal instruments establishing the international tribunal will usually contain the rule relating to the exhaustion of local remedies, which then acts as a jurisdiction-regulating rule. In the absence of such a provision, the Court may have to rely on other jurisdiction-regulating rules to determine its competence to hear a matter involving a domestic court.

\subsection{Jurisdictional Relations between the ECOWAS Community Court of Justice and National Courts}

As noted above, there is no rule on the exhaustion of local remedies in the Protocols relating to the EcowAs Court. Nevertheless, the Court has had to

\footnotetext{
63 Shany, supra note 41; Shany, supra note 47.

64 See F. Viljoen, 'Admissibility under the African Charter', in M.D. Evans and R. Murray (Eds), The African Charter on Human and Peoples' Rights: The System in Practice, 1986-200o (Cambridge University Press: Cambridge, 2001) p. 92.

65 See Article 56(5), African Charter on Human and Peoples Rights; Art 35(1), European Convention on Human Rights; Article 46(1), American Convention on Human Rights; Art 41(1)(c), International Covenant on Civil and Political Rights; Article 11(3), International Covenant on the Elimination of All Forms of Racial Discrimination; Article 15(2), SADC Protocol on the Tribunal and Rules of Procedure Thereof.

See Shany, supra note 47 .
} 
entertain matters that call into question its relationship with Member state courts where such actions have been heard in national courts or remain pending before them.

From the provisions of Article 10(d) of the 2005 Supplementary Protocol on the ECOWAS Court, the two statutory restrictions to the admissibility of actions before the Court are the submission of anonymous applications and the pendency of the same matter before another international Court. ${ }^{67}$ These are the treaty-based jurisdiction-regulating rules; in addition, the Court has also made declarations on the (positive) determinants of its jurisdiction. In Manneh v. the Gambia, ${ }^{68}$ the Court confirmed the rules governing its jurisdiction as laid down in Alhaji Hammani Tidjani v. Nigeria and 4 Others ${ }^{69}$ thus,

...the combined effect of article 9(4) of the Protocol of the Court, as amended, article $4(\mathrm{~g})$ of the Revised Treaty and ... the African Charter on Human and Peoples' Rights is that the plaintiff must invoke the Court's jurisdiction by (i) establishing that there is a right recognized by ... the African Charter on Human and Peoples Rights; (ii) that this right has been violated by the defendant; (iii) that there is no action pending before another international Court in respect of the alleged breach of his right; and (iv) that there was no previously laid down law that led to the alleged breach of abuse of his rights. ${ }^{70}$

From the above, it is clear that the jurisdiction of the Court will not be restricted by judicial or other proceedings pending in domestic courts or institutions of Member States. This confirms that the exhaustion of local remedies rule is not a compulsory jurisdiction-regulating rule in resolving competing jurisdictional claims between domestic and international tribunals, but rather, that its omission can signify the definition of the relationship between such tribunals. Although the exhaustion of local remedies rule is recognized as a rule of customary international law, its original application applied mainly to the original reference to diplomatic protection. Amerasinghe notes that

67 The latter is an expression of the electa una via rule, which is a non-hierarchical horizontal jurisdiction-regulating rule. See Ibid., p. 36.

68 ECW/CCJ/JJD/o3/o8 (June 2008), available in Ebobrah and Tanoh, Compendium of African Sub-Regiona Human Rights Documents (Pretoria University Law Publications, Pretoria, 2010), p. 265 .

69 ECW/CCJ/APP/o1/o6 (June 2007).

$70 \quad$ Ebobrah and Tanoh, supra note 68, p. 285, para. 16. 
The systematic protection of the national against his own state...can only be based on a broader acceptance of substantive rules and principles relating to human rights which apparently are only coming to be recognized, if at all, in customary international law. In any case, the remedies for the protection of human rights as such come through the medium of conventions and agreements. The implementation of protection remedially can only be determined by the provisions of such instruments, since there is no procedure at customary or general international law to secure the implementation of such protection, particularly against national states of the injured individual. Thus, at present it is to the instruments by which such protection is implemented that resort must be had in order to discover whether and to what extent the rule of local remedies is applicable to the scheme of such protection. ${ }^{71}$

Therefore, the application of such jurisdiction-regulating rules, in the case of international protection of human rights, is usually restricted to the provisions of the treaty or agreement granting jurisdiction, the content of which are imperative to the interpretation of the jurisdiction of international tribunals. In this regard, the relevant documents for the interpretation of the jurisdiction of the ECOWAs Community Court of Justice are the 1991 Protocol, the 1993 Revised ECOWAS Treaty, the 2001 Supplementary Protocol, and the 2005 Supplementary Protocol. A collective interpretation of these instruments does not limit the jurisdiction of the Court to cases that have been exhausted in domestic tribunals or which are not pending before domestic tribunals. In fact, the Court has stated on several occasions that the determination of its jurisdiction is limited to these statutes. In Registered Trustees of the Socio-Economic Rights \& Accountability Project (SERAP) v. Federal Republic of Nigeria \& Another, ${ }^{72}$ the Court noted that

It is a well established principle of law that jurisdiction is a creature of statute. The statute that spells out the jurisdiction of this Court is the Supplementary Protocol on the Court of Justice, specifically Article 9 thereof. For this Court to have subject-matter jurisdiction over the suit as instituted by the plaintiff, the subject matter of the suit must fall within

71 Amerasinghe, supra note 6o, p. 66.

72 ECW/CCJ/APP/o808 (October 2009), in Ebobrah and Tanoh, supra note 68, p. 298, para. 10. 
the confines of Article 9 of the Supplementary Protocol to the Court.... The Court has jurisdiction over human rights enshrined in the African Charter and the fact that these rights are domesticated in the municipal law of the Federal Republic of Nigeria cannot oust the jurisdiction of the Court... This Court clearly has subject matter jurisdiction over human rights violations in so far as these are recognized by the African Charter on Human and Peoples' Rights, which is adopted by Article 4(g) of the Revised Treaty of EcowAs.

Also, in Keita and Another $v$ Mali, ${ }^{73}$ the Court stated that

... as regards material competence, the applicable texts are those produced by the Community for the needs of its functioning towards economic integration: the Revised Treaty, the Protocols, Conventions, and subsidiary legal instruments adopted by the highest authorities of ECOWAS. It is therefore the non-observance of these texts which justifies and founds the legal proceedings brought before the Court. From this standpoint, the Court has to determine the extent to which the Application instituting proceedings makes a demand on any Community text.

In addition, the omission of the local remedies rule in the relevant texts of the Community Court can only be regarded as intentional. Before the expansion of access to the Court to include applications by individuals, the Community leadership had thought it fit to adopt the rule relating to the exhaustion of local remedies under the 2001 Supplementary Protocol. This was an expression of the rule in its original historical context, which is in the area of diplomatic protection. Therefore, under the 2001 Supplementary Protocol, the rule would apply in actions brought by States against other States for the protection of the rights of the former's citizens. ${ }^{74}$ However, the Community did not intend to extend this to the more contemporary practice of human rights applications by the individual and, hence, left it out of the 2005 Supplementary

73 ECW/CCJ/APP/o3/o7 (March 2007), in Ebobrah and Tanoh, supra note 68, p. 266, para. 27.

74 See Amerasinghe, supra note 60. 
Protocol. ${ }^{75}$ This has been confirmed in Koraou v. Niger, ${ }^{76}$ where the Court noted that

In refraining from making the rule of preliminary exhaustion of local remedies a condition for admissibility of applications filed before the Court, the Community lawmaker of EcowAs has undoubtedly responded to... [a call for States to renounce the rule of exhaustion of local remedies in response to the evolution of international practice]. The renunciation of such a rule is binding on all the member states of EcowAs.

This shows that there was a deliberate renunciation of the rule based on the intention of the drafters of the 2005 Protocol to expand the jurisdiction of the Court beyond traditional limits to ensure that the Court exercises jurisdiction under circumstances that would be otherwise restricted in other international tribunals. ${ }^{77}$ The Court has made this clear in its judgments. In Essien v. The Republic of the Gambia and Another, ${ }^{78}$ the Court noted that Article 50 of the African Charter on Human and Peoples' Rights, which contains the provision on the exhaustion of local remedies, would not affect its own jurisdiction as "the

75 Cf., The Loewen Group, Inc. and Raymond L. Loewen v. The United States of America (ICSID Case No. ARB(AF)/98/3) at para 73, where the Arbitration Tribunal held that

"We accept that an important principle of international law should not be held to have been tacitly dispensed with by an international agreement, in the absence of words making clear an intention to do so (Elettronica Sicula SpA (Elsi) (United States $v$ Italy) (1989) ICJ 15 at 42). Such an intention may, however, be exhibited by express provisions which are at variance with the continued operation of the relevant principle of international law."

Therefore, according to Loewen, in the absence of express words precluding the application of the local remedies rule, the rule would be applicable in international actions. This position seems to make the rule a rule of customary international law that is binding on relevant actors, a conclusion which is not exactly tenable. International institutions may introduce jurisdiction-regulating rules in their relations with national and other international institutions, but this does not give them the power to introduce universal rules binding on all such relations.

76 ECW/CCJ/JJD/o6/o8 (October 2008), in Ebobrah and Tanoh, supra note 68, p. 286, para. 40.

77 Cf., S. Ebrobah, 'A Rights Protection Goldmine or a Waiting Volcanic Eruption? Competence of, and Access to, the Human Rights Jurisdiction of the EcowAs Community Court of Justice'. 7 African Human Rights Law Journal (2007), 307-327, at p. 327, where the author argues that the failure to include the local remedies rule in the relevant texts does not signify an absolute renunciation of the rule.

78 ECW/CCJ/APP/05/05 (March 2007), in Ebobrah and Tanoh, supra note 68, p. 271. 
said article refers not to any organization but the Commission. Consequently that provision of article 50 cannot be applied stricto senso to this case pertaining to the exhaustion of local remedy and its relevance to this Court", and the Court stated further that "it is trite that competence of the Court is enshrined in articles 9 and 10 of the Supplementary Protocol".79

The local remedies rule depicts that international human rights tribunals are meant to play a somewhat supervisory role in the protection of human rights and to intervene where the domestic courts have refused or failed to protect the rights in question. It implies powers of review over the decisions of domestic courts and institutions, almost like an appellate court. Although judicial review can be interpreted from a relationship of unidirectional bindingness, Shany notes that while hierarchy usually empowers a court to exercise judicial review over another, judicial review in itself is not necessarily a sine qua non for ascertaining inter-fora hierarchy. ${ }^{80}$ The ECOWAS court has also attempted to describe its relationship with domestic courts in this regard. In Ugokwe v. Nigeria and Others, ${ }^{81}$ the Court categorically stated that

Appealing against the decision of the National Court of Member States does not form part of the powers of the court; the distinctive feature of the Community legal order of EcowAs is that it sets forth a judicial monism of first and last resort in Community Law. And, if the obligation to implement the decision of the Community Court of Justice lies with the national courts of Member States, the kind of relationship existing between the Community Court and these national courts of Member States, but demands an integrated legal order. The Ecowas Court of Justice is not a Court of Appeal or a Court of cassation ... as to the orders being sought against the execution of the judgement already made by the Federal Appeal Court of the Member State of Nigeria - the Court is incompetent. ${ }^{82}$

In Keita, ${ }^{83}$ the Court noted that it would not have the power to deliberate on the decisions of national courts. Therefore it does not have powers of review. The Court said that

79 Ebobrah and Tanoh, supra note 68, p. 276, para. 23.

8 o Shany, supra note 47, p. 89 .

81 ECJ/CCJ/APP/o2/o5 (October 2005), in Ebobrah and Tanoh, supra note 68, p. 261.

82 Ebobrah and Tanoh, supra note 68, p. 265, paras $3^{2-33}$.

83 Keita, supra note 73 , para. 27. 
Moussa Leo Keita complaints [sic] of being a victim of injustice committed by his State, and of the malfunction or poor running of the justice system of his country. In this perspective, the Community Court of Justice is powerless: it cannot adjudicate upon the decisions of the national courts. Within the meaning of the aforementioned Article 10, the Community Court of Justice can only intervene when such courts or parties in litigation expressly so request it within the strict context of the interpretation of the positive law of the Community. Hence, the objection raised by the Defence regarding the rationae materae competence of the Court must be declared admissible.

While, in Koraou v. Niger, ${ }^{84}$ the Court stated that

... the arrest and detention of the applicant were carried out in implementation of the judicial decision made by the... Konni Criminal Court [a domestic court of Niger]. This decision constitutes a legal basis [for the arrest and detention], and it does not fall within the jurisdiction of the Court to consider whether such a decision is well founded or ill founded.

Based on the above decisions, it is clear that the Court does not see itself as a review or supervisory mechanism for decisions coming from national courts. Having established that the local remedies rule will not apply in the ECOWAs Court, which also does not have a power of judicial review over national courts, we must determine the nature of the relationship between the Court and domestic courts. We must determine whether it is a hierarchical or non-hierarchical relationship in order to determine the types of jurisdictionregulating rules that will apply in such relations.

Shany recognizes two hierarchy signifiers, viz, permissible multiplicity and unidirectional bindingness. He claims that where it is permissible to commence multiple proceedings before different courts and the decisions of one court are binding on another, then we have a system of hierarchy. Conversely, where it is not permissible to commence multiple proceedings before different courts, this is a non-hierarchy signifier. ${ }^{85}$ There is nothing in any of the jurisdiction-regulating instruments mentioned above that permits or precludes multiplicity of proceedings between the EcowAs Court and national courts, although Article 22(2) of the 1991 Protocol may be interpreted - very broadly to partially preclude multiple proceedings. That provision states that

$84 \quad$ Koraou, supra note 76 , para. 91.

85 Shany, supra note 47, p. 87 . Here, Shany notes that the electa una via rule and the doctrine of complimentarity are non-hierarchy signifiers. 
When a dispute is brought before the Court, Member States or Institutions of the Community shall refrain from any action likely to aggravate or militate against its settlement.

Under desperate circumstances, this provision may be interpreted as precluding courts in Member States from entertaining matters that have been brought before the Court. This might seem an extreme interpretation of the provision, since it does not preclude parallel attempts at settling the dispute, but rather prevents actions that would aggravate the dispute or militate against settlement. In addition, as will be noted below, the international obligation of States does not bind their courts directly, so such a provision that places obligation on 'Member States' does not place any direct obligation on their courts. Therefore, the interpretation of the existence of this requirement will depend on the Court's interpretation of the relevant instruments in determining its relationship with Member State courts and vice versa. So far, the EcowAs Court has not attempted any such broad interpretation. In Koraou, the respondent State raised a preliminary objection on the admissibility of the application before the Court on the ground that domestic proceedings were still pending. The Court held, in response, that

Consequently, by providing for article $10(\mathrm{~d})(\mathrm{ii})$ of the Supplementary Protocol in the manner it did, the Community lawmaker of Ecowas intended to remain within the strict confines of what international practice has deemed appropriate to abide by. It is therefore not the duty of the instant Court to add to the Supplementary Protocol conditions which have not been provided for by the texts. Ultimately, and for all these reasons, the objection raised by the defendant cannot thrive.

Therefore, by restricting itself to a strict and somewhat inflexible interpretation of the jurisdiction-conferring instruments, the Court appears to favor an interpretation that permits multiplicity of proceedings. This reading would indicate a fulfillment of the first hierarchy signifier.

With regard to the second hierarchy signifier, there is no express provision in any of the relevant instruments that makes the decisions of the EcowAS Court binding on the domestic courts of Member States. ${ }^{86}$ On the relationship

86 Article 33 of the Treaty for the Establishment of the East African Community, for instance, provides that

1. Except where jurisdiction is conferred on the Court by this Treaty, disputes to which the Community is a party shall not on that ground alone, be excluded from the jurisdiction of the national courts of the Partner States. 
of the Court with national courts, Article 10(f) of the Protocol provides for national courts to refer cases to the Court where such cases concern interpretations of the Treaty, or any Protocol or Regulation. ${ }^{87}$ This provision allows for preliminary ruling, which Shany regards as a signifier of a vertical hierarchical relationship but also with elements of a horizontal nature. ${ }^{88}$ The requirement under the Protocol only applies to cases dealing with interpretation of the Treaty and other Community instruments and not to general substantive or procedural issues, thus revealing a limited jurisdiction-regulating rule. ${ }^{89}$ This is the extent of direct reference to and regulation of the relationship between the Court and national courts in the relevant Community texts.

Regarding general bindingness of the Court's decisions, Article 15(4) of the Revised Ecowas Treaty provides that the judgment of the Court shall be binding on "Member States, institutions of the Community, and on individuals and corporate bodies", while Article 62 of the Rules of Procedure of the Community Court of Justice of the Economic Community of West African States (ECOWAS), 2002, provides that "The judgment shall be binding from the date of its delivery". Article 22(3) of the 1991 Protocol also provides that "Member States and Institutions of the Community shall take immediately all necessary measures to ensure execution of the decision of the Court". With regard to this kind of obligation, Ebobrah and Nkhata note that "the relation of the international judicial fora is to the state and not to the judicial institutions of the state". ${ }^{90}$ Granted, the state consists of different organs, including legislative, executive and judicial organs, but, as Ahdieh notes, "Such interbranch engagement among international courts and national executive and legislative agencies... is different in kind from the assertion of power among

2. Decisions of the Court on the interpretation and application of this Treaty shall have precedence over decisions of national courts on a similar matter.

87 Article 4 of the 2005 Supplementary Protocol amends the provisions of Article 10 of the 1991 Protocol on the access to the Court and includes, inter alia, that

"Where in any action before a court of a Member State, an issue arises as to the interpretation of a provision of the Treaty, or the other Protocols or Regulations, the national court may on its own or at the request of any of the parties to the action refer the issue to the Court for interpretation."

88 See Shany, supra note 47, p. 33, noting that there is a 'division of labour' attribute of the procedure that reveas elements of a horizontal nature.

89 Ibid., 35 .

go S. Ebobrah and M.J. Nkhata, 'Is the SADC Tribunal under judicial siege in Zimbabwe? Reflections on Etheredge $v$ Minister of State for National Security Responsible for Lands, Land Reform and Resettlement and Another', ${ }_{43}$ Comparative and International Law Journal of Southern Africa (2010), 81-92, at p. 91. 
judicial institutions". ${ }^{91}$ Courts are bound by the jurisdiction-conferring instruments that establish and regulate them, and they would be hard-pressed to grant supervisory jurisdiction to other institutions where such jurisdiction is not provided for in their constitutive and regulatory instruments. Therefore, international tribunals have the capacity to influence the decisions of national courts through the pronouncement of the obligation of states, but they cannot bind national courts in the absence of any direct and express provision to that effect. ${ }^{92}$ Many of the interactions between international judicial organs and states happen through the executive and legislative organs of those states, while the courts rely largely on national law to determine hierarchy and bindingness of court decisions. ${ }^{93}$ Therefore, in the absence of express provisions stating the bindingness of the decisions of the Court on national courts, the decisions of ECOWAs Court are not binding on national courts.

Another important question would involve the extent to which the decisions of Member State courts are binding on the Court. Would the insistence of the Court that it does not have the power of judicial review over national courts create a relationship where the decisions of Member State courts are binding on the Court? The Court has described itself as a court of 'first and

$91 \quad$ Ahdieh, supra note 52, p. 2059.

92 Ahdieh, supra note 52, pp. 2059, 2102. The role of the Nigerian federal executive branch, through the Office of the Attorney General of the Federation, in suspending the enforcement of the decision of the Court of Appeal in Ugokwe following an interim order by the ECOWAs Community Court of Justice to that effect, presents a good example of this kind of influence. See K. Alter, L. Helfer and J. McAllister, 'A New International Human Rights Court for West Africa: The EcowAs Community Court of Justice', 107 American Journal of International Law (2013), 737-779.

93 This question of bindingness has not been considered by any national court in West Africa. During the pendency of the Ugokwe suit, all discussions and opinions by Nigerian officials in this regard were extra-judicial. See Alter et al., supra note 92, p. 23. But, in Southern Africa, a Zimbabwean court held, in Richard Thomas Etheredge $v$ The Minister of State for National Security Responsible for Lands, Land Reform and Resettlement and Another (HC 3295/o8, Unreported), that the decisions of the Community Court of the Southern African Development Community (SADC) were not binding on the national courts of Zimbabwe. The Zimbabwean court relied on the Zimbabwean Constitution as the jurisdiction-regulating mechanism in the case of jurisdictional overlap, despite the requirement for exhaustion of local remedies in Article 15(2) of the SADC Protocol on the Tribunal and Rules of Procedure Thereof (see Ebobrah and Nkhata, supra note 90, for a discussion of the Zimbabwean court's decision). Therefore, even in the presence of hierarchy signifiers, it is possible for national courts to deny the bindingness of regional court decisions on them. 
last resort', ${ }^{\prime 4}$ and, although it does not have the power of judicial review over national court decisions, it does not seem to regard such decisions as binding on it.

Based on the above, the requirement of unidirectional bindingness appears to be absent in the relationship between the Court and the courts of Member States, thus signifying a non-hierarchical relationship. However, Shany also notes that a significant non-hierarchy signifier is the prohibition or preclusion of multiple proceedings, which is absent from the Court's relationship with national courts. Therefore, the ECowAs Court, in its relationship with national courts, seems to exist somewhere between hierarchy and non-hierarchy in a realm of vertico-horizontal relations. This relationship also falls within Ahdieh's concept of dialectic review, under which "neither court can impose its will on the other, producing a degree of incident autonomy within an overall pattern of systemic dependence" ${ }^{95}$

\subsection{Competing Competences: The Good, the Bad and the Ugly}

Competition exists under the following situations: where there is a nonhierarchical relationship between the institutions in question; where there are jurisdictional overlaps; and where parties may choose one or both of the judicial options available for the settlement of their disputes. Where, as Shany notes, the judicial systems exist as alternatives to one another, there is the possibility - the likelihood - of competition. Citizens may then choose, depending on their perception of which system offers better access to justice, which of the alternative institutions to lay their claim.

Based on the above, the non-bindingness of the Court's decisions on national courts - and vice versa - indicates something of a horizontal nonhierarchical relationship between the Court and national courts. It is argued that, by extension, this relationship is of a somewhat vertico-horizontal nature, requiring the Court to determine cases based on the relevant Community texts, but also taking into consideration the level of autonomy which State courts have in response to its decisions. This was the case in Ugokwe, where significant outcry in Nigerian public circles led the Court to reconsider and reverse its preliminary decision that amounted to a review of a national court decision. ${ }^{96}$ Therefore, the autonomy of the Court is restricted by the influence

94 Ugokwe, supra note 81, para. $3^{2}$.

95 See Ahdieh, supra note 52, p. 2090. The autonomy is based on the non-bindingness of the decisions of international tribunals on national courts, while dependence is based on the international obligation of States, which translated to a binding obligation on State organs that can influence the decisions of the international tribunal. 
of autonomous national courts on the recognition and implementation of its decisions. Nevertheless, based on Community texts and the jurisprudence of the Court, the relationship between the Court and national courts is nonhierarchical. The nature of this relationship fulfills the first requirement for competition.

The Court's human rights jurisdiction, which is based on the provisions of the African Charter, covers rights that are protected under the constitutional bill of rights of Member States; therefore, the possibility of jurisdictional overlap in human rights actions is very high, thus fulfilling the second requirement for competition.

We can safely assume that the ECOWAs Court provides an alternative for disputants to choose between the Court and national courts, neither of which exercises a supervisory role over the other, since both institutions exist in a space that allows for multiplicity of proceedings. Thus, litigants can bring their action in their national court or the EcowAs court or in both courts simultaneously.

The fact that parties may choose between bringing an action in the domestic court and in the ECOWAS Court or do both - signifying alternatives - reveals a horizontal relationship between both systems, but because of the possibility of multiple proceedings and the influence of the Court's decisions on national courts through the binding nature of international obligations on state organs, there is a somewhat vertical twist to this relationship..$^{97}$ Therefore, the relationship between the Court and national courts can be regarded as both vertical and horizontal, in that it contains important elements of international judicial power by which the Court can bind Member State institutions, which may in turn influence national courts; in addition, it contains the practical hierarchy signifier of permissibility of multiple proceedings. ${ }^{98}$ In essence, permissible multiple proceedings and the resultant challenges that come with that necessitate the introduction of jurisdiction-regulating rules to address such challenges.

The relevant Community texts and the jurisprudence of the Court do not provide clear jurisdiction-regulating rules to define and govern its relationship with national courts, and, as can be seen from the above examples, the Court

97 As Shany notes that "hierarchical relations negate the possibility of viewing parallel proceedings as judicial alternatives to one another", it can safely be assumed that nonhierarchical relations provide this possibility. Shany, supra note 47, p. 88.

98 Ahdieh's dialectical review reveals an 'equipoise of power' in which international judicial power based on non-voluntary access is balanced by national autonomy. See Ahdieh, supra note 52, p. 2090. 
has been reluctant to make direct pronouncements on the application of relevant jurisdiction-regulating rules, whether this means applying recognized rules or introducing new ones. ${ }^{99}$ This means that there is still ample room for the Court to introduce the application of rules that will strike a balance between access to justice and judicial regulation in defining its relationship with national courts in Member States.

In summary, rather than act as a supervisory mechanism, the Court exists as an alternative judicial system for citizens, resulting in competition between institutions. ${ }^{100}$ This way, citizens have direct access to judicial institutions at the national and regional level, that are capable of protecting their nationally and internationally guaranteed rights. Thus, what we have in the case of the ECOWAs Court is a system of competing competencies, such that the competence - or lack thereof - of the domestic system determines recourse to the international (regional) system.

Considering the institutional challenges experienced by Member States, the situation of competing competences is a welcome interpretation of the jurisdictional reach of the ECOWAs Court, particularly as a means of enhancing access to justice for Community citizens. The institutional failure of national systems has thus led citizens to seek alternatives outside their national judicial systems. The alternatives include resort to courts of other countries and resort to regional courts and tribunals such as the EcowAs Court of Justice and the African Court of Human and Peoples' Rights. The extent to which these alternatives create viable access to justice opportunities depends on how jurisdiction-regulating rules limit or promote direct access to the courts. In this regard, the Ecowas Court has declined to apply some of these jurisdictionregulating rules that would restrict citizens' access to the Court.

The main consideration for expanding the rules of access to the Court to include individuals came from a clamour to improve access to justice for individuals at the regional level. This was noted particularly in relation to the utilization of the Court by individuals after the former's initial entry into

99 The Court does not make reference to rules such as res judicata or lis alibi pendens, even where the facts of the case require consideration of the application of such rules; for example, in the Koraou case, supra note 76, the Ugokwe case, supra note 81, and the Keita case, supra note 73. It does not, like the Loewen Tribunal seek to introduce new jurisdiction-regulating rules, such as the rule of judicial finality.

100 Shany notes that, "While Courts situated in a hierarchical relation may interact with one another, they cannot conceivably compete with one another" Shany, supra note 47, p. 6. Therefore, by necessary implication, in the absence of such hierarchy, there is competition. 
operation. ${ }^{101}$ The Court noted that one of the features of an advanced regional integration process was the accessibility of regional courts and tribunals to individuals in order to safeguard the human rights of the latter. ${ }^{102}$ Therefore, the Court, since the adoption of the 2005 Supplementary Protocol, has ensured that it serves as a mechanism for promoting the right of access to justice for Community citizens, particularly in situations where national justice systems are unable or unwilling to protect this right.

While the promotion of access to justice is in itself a positive outcome of this development in regional integration, the expansion of the Court's jurisdiction and rules of access does not come without its own challenges. Some of those challenges are tied to the manner in which the Court translates its relationship with domestic courts. For example, in the absence of strict jurisdiction-regulating rules, there is the concern that there will be multiplicity of proceedings in both systems.

Having multiple proceedings in different systems can indeed lead to multiple problems, including the delivery of conflicting judgments by both courts, which would lead to problems of enforcement and increased tension between institutions at the regional and national level. ${ }^{103}$ Since the Court does not play a supervisory role in its relation to domestic courts, its decisions do not overrule, nor do they confirm, national court decisions. They both exist on different planes; therefore, in cases involving the same parties, different judgments can create confusion, as can similar judgments, because implementation is based on distinct, independent decisions by different courts. ${ }^{104}$ The absurdity raised by this situation cannot be underemphasized. In the absence of a longstanding relationship between institutions, based on comity and dialogue, it is difficult to keep track of multiple proceedings and contrasting decisions and respond to them.

In the ECOWAs context, there is little communication between the Court and domestic courts, and one of the challenges faced by the Court is the lack

101 The first case to be heard by the Court (Olajide Afolabiv. Federal Republic of Nigeria, ECW/ $\mathrm{CCJ} / \mathrm{APP} / \mathrm{or}_{\mathrm{o}}$ ) was filed by a Nigerian trader against the Nigerian government for violation of Community law and of the applicant's human rights. The case was dismissed by the Court for lack of jurisdiction based on the provisions of the 1991 Protocol, which did not allow individuals access to the Court. See Alter et al., supra note 92 and Ebobrah, supra note 76 , for a detailed discussion of the court's jurisdictional evolution.

102 See A. Banjo, 'The ecowas Court and the Politics of Access to Justice in West Africa', 32 Africa Development (2007), 69-87, at p. 83 .

103 Viljoen, supra note 64; Ebobrah, supra note 101, p. 329; Shany, supra note 47 p. 34.

104 This challenge is reduced by the dissimilarity in parties, subject matter and cause of action in parallel proceedings before courts from different spheres. 
of awareness in Member States about its activities. While this situation has improved since the establishment and operation of the Court, it still remains a challenge that must be addressed. One of the institutions that can provide considerable assistance in this regard is the EcowAs Judicial Council, which was established by a Decision of the Authority of Heads of State and Government in 2006. ${ }^{105}$ The Council comprises the Chief Justices of Member States and is responsible for the appointment and discipline of Judges of the Court. It also provides a balancing mechanism for appointment of Judges, which was left entirely to the Authority of Heads of State and Government under the 1991 Protocol. ${ }^{106}$ The Council can serve as a mechanism for determining jurisdiction-regulating rules that would eliminate - or at least reduce - the confusion that can be created by the current somewhat unregulated relationship between the Court and Member States, while also preserving the access to justice role of the Court. In addition, by serving as a bridge between national courts and the Court, the Council can also serve as a capacity building mechanism for weak national systems.

In addition to the challenge of multiple proceedings, another challenge that may be faced by the Court is one of capacity. The Court comprises seven judges in a region with a population of more than 300 million people. Considering its role as an alternative promoter of the right of access to justice in a region with weak justice institutions that are unable to guarantee the protection of this right, the Court can expect an increasing number of cases to come before it as the years go by. ${ }^{107}$ It would be important for the Council and the Authority to explore the option of enhancing and improving the capacity of the Court by increasing the number of Judges and officials of the Court, as well as expanding the reach of the Court by establishing national offices in Member States.

Despite the above caveat, the Court has not been inundated with applications from across the region. Most of the applications that have come to the Court have been brought by Nigerians; this might have something to do with the fact that the Court is located in Abuja, the Nigerian capital, and the significant population of that Country. ${ }^{108}$ Access to the Court for Community

105 Decision A/Dec.2/o6/o6. See Alter et al., supra note 92, pp. 24-25.

106 See Article 3, 1991 Protocol.

107 The Supreme Court of Ghana alone has fourteen Justices, while the Supreme Court of Nigeria has eleven Justices. These are supervisory courts which hear appeals as the final courts of the land, as opposed to the Ecowas Court which, although a final court in its own right, hears cases at first instance.

108 For a list of cases entertained by the Court from inception till date, see http://www. courtecowas.org/site2012/index.php?option=com_content\&view=article\&id=157\&Ite mid=27 (accessed 28 October, 2013). 
citizens is still a challenge and is more limited than domestic courts in practical and logistical terms, for example, financial and geographical constraints can keep citizens from having access to the Court. ${ }^{109}$ Nevertheless, the Court provides an alternative judicial system that is functional and devoid of many of the institutional challenges that beset domestic courts. Therefore, relevant actors and stakeholders can begin to pursue relevant policy changes that will address the operational and logistical challenges that continue to keep citizens from accessing the Court.

In conclusion, the Court addresses a very important substantive challenge that has kept Community citizens from accessing justice in their home states. Many of the challenges associated with the structure and performance of the Court can be addressed by introducing policy mechanisms and creating a regulatory mechanism for defining and managing the relationship between the Court and Member State courts.

We have seen, from the above, that there is a need to strengthen judicial and other political institutions in West African States. One of the ways to enhance this process of institution-building is through integration. Regional integration in West Africa has been regarded as a tool for enhancing development by developing regional institutions that can implement policies that meet the demands of citizens on a regional scale.

In 2006, ECOWAS transformed its institutions to make itself more accessible to Community citizens, so the focus of the Community shifted from states to individuals or people. This meant that the Community's institutions changed their focus from broad development goals that focused on State institutions to more concise goals targeted at Community citizens. Among the transformations during this period was the transformation of the Community Court of Justice, established pursuant to the 1975 Treaty establishing the Community, empowering it to entertain applications from individuals for the protection of their internationally guaranteed human rights. This modified access to the Court is very wide, such that the Court may serve as a tribunal of first instance in relevant matters, without the requirement that applicants exhaust domestic remedies before approaching the Court. Based on relevant discussions about the relationship between national and international tribunals, this reveals a non-hierarchical relationship, in which the competing competences of the

109 See Banjo; Alter et al., supra note 92. 
national and international systems provide access to alternate judicial systems, so that the demands and expectations of citizens are met.

This position is not without its challenges and must be regulated in order to address operational challenges arising from multiple proceedings and conflicting judgements, but the jurisprudence of the Court reveals an avid willingness to deliver a public good by ensuring that citizens' rights of access to justice are met by committed judicial institutions. This competition will, hopefully, encourage Member State courts to provide more effective and efficient delivery of justice as a public good to their citizens. The Court will also serve as a capacity-building mechanism for national courts and vice versa, as dialogue encourages continuity and stronger institutional responses at both the national and international level.

\section{Acknowledgements}

The author appreciates the useful comments of Professor Benedict Kingsbury, Professor Laurence Helfer and Dr Sope Williams-Elegbe on earlier drafts of this article. 